\title{
The Moral Economy of Thrift: The Production of the Indebted Self in the Reality TV-series Getting Out of Debt and Life or Debt
}

\author{
By Silke Meyer
}

\begin{abstract}
In this article, the intersection of the economic and social dimensions of thrift is analysed under the special condition of debt. The debt context serves as a focal glass exposing agents, their social practices and strategies of accumulation capitals with regard to appropriate spending. In order to capture the many layers of thrift, the concept of moral economies is applied. This concept tries to reconcile two seemingly divergent dimensions of human behaviour which can be described as individualistic, calculating and serving a self-interest (economy) on the one hand and community-oriented and benefitting a common good (morality) on the other hand. Starting out with an overview over studies on moral economies in historical and social science since the early 1970s, I will explain the heuristic use of the concept for the case of debts research and apply it to representations of thrift as visualised and popularised in the reality TV shows Raus aus den Schulden (Getting Out of Debt) and Life or Debt. Here, the images of homes are clues for the cultural productions of appropriateness on TV: What are suitable ways of living when in debt? What are adequate scenes of dwelling and narratives of dealing with debts and which normative structures regulate those stories, the perception of the self and potential social exclusion? By examining the TV show as a strong voice in the debt discourse, thrift turns out to be a cornerstone in the internal and external regimes of governing debt in the micropolitics of TV.
\end{abstract}

Keywords: Debts, debt discourse, reality TV, subjectification, moral economy.

Meyer, Silke: "The Moral Economy of Thrift: The Production of the Idebted Self in the Reality Series Getting out of Debt and Life or Debt", Culture Unbound, Volume 12, issue 3-4, 2019: 485-500. Published by Linköping University Electronic Press: http://www.cultureunbound.ep.liu.se 


\section{Introduction}

Economic practices are also moral practices, and economic anthropology is mostly interested in this hybrid character. The notion of thrift is a perfect example of the nexus of economic decisions and moral orders: Thrift means economising appropriately, with an eye to social norms, situations, and interactions. In their seminal paper, Aneta Podlicka and Jason Potts described thrift as "consuming wisely and resourcefully" (2013:2) and emphasised the long-term perspective of mindful consumption and careful prosperity. The argument of appropriateness is so engaging that we almost forget to enquire: Who gets to decide what is appropriate, wise, and resourceful for whom (and what is not)? What are the historical and social specifics of mindful consumption and careful prosperity? Historically, the answer to these questions is the idea of the bourgeois. Thrift developed its moral gravity with industrialisation: Its social status started out as an entirely unremarkable quality of human life which turned into the signature feature of respectability and virtue within the middle classes during the rise of industries and capitalism (McCloskey 2011). With deep historical roots in middle-class values, thrift still achieves social viability by offering a sense of social positioning, acceptance, and belonging.

In the following article, I will analyse the logic of thrift, its moral order, and its social class convention through the perspective of debt. The context of debt serves as a specific lens demonstrating the moral dimension of thrift through its mode of operation as cultural capital. Debtors experience economic and social exclusion because they have proven to be the opposite of thrifty; they have not spent their resources wisely, they have lived beyond their means and have to be corrected and educated. I will look at representations of those ways of educating not only debtors but also the audience of popular TV shows that deal with personal bankruptcy. In analysing and comparing a German and a US TV show, I aim to deconstruct the making of an indebted self within its historical and social context. My focus is on the role of thrift-when in debt, the thrift economy contains a social promise of belonging and can be used to mend financial and moral mistakes.

In order to grasp the social distinction included in thrift, I will employ the concept of moral economies. Starting out with a short history of the concept since the early 1970s, I will outline the heuristic benefit of the concept in order to study the nexus of economy, debt, and social class. I will thereby draw on representations of thrift as visualised and popularised in the reality TV show Raus aus den Schulden (Getting Out of Debt) and compare them with the US show Life or Debt. In both shows, the images of homes are clues to the cultural production of appropriateness: What are suitable ways of living when in debt? What are acceptable scenes of dwelling and narratives of dealing with debt and which normative structures regulate those stories, the perception of the self, and 
potential social exclusion? Representations of thrift hereby use the heavy weight of middle-class history to convince the audience of the rights and wrongs of being in and getting out of debt. Thrift here turns out to be a cornerstone in the internal and external regimes of governing debt in the micropolitics of TV. The twist, however, lies in a broken bond. While thrift and appropriate ways of dealing with debt invoke the promise of social inclusion, the TV shows send a different message. Debt is shown as an individual, even personal, problem. Getting out of debt is therefore a personal achievement, making political and structural reasons for financial problems invisible.

\section{What Makes a Moral Economy?}

The history of an idea is more easily written when there are founding figures, in this case a founding father. ${ }^{1}$ The historian Edward Palmer Thompson studied food protests embedded in what he called the moral economy of eighteenth-century English crowds (Thompson 1971, 1991). Although Thompson did not invent the term, it is interesting that he so famously applied it to a period when morality and economy seemed to have begun to go their separate ways. From about 1750 to 1850 , industrialisation paved the way for early capitalism at the expense of social justice with individual needs outranking the idea of a common good. It is certainly no coincidence that it was eighteenth-century thinkers who felt the need to reconcile the spheres of the moral and the economic. Jean-Jacques Rousseau, for example, promoted the general will (volunté general) as a moral economy. According to Rousseau, if public and private welfare followed principles of reciprocity, individuals would act morally and not maximise their own fortune at the cost of others (Götz 2015: 149).

Since then, the term has gained currency in historiography as well as in the social and political sciences, while, at the same time, its scope has broadened. Initially, as in Thompson's work, it was used to describe "some legitimating notion" of the social groups who revolted against impending changes to society's economic and social fabric in pre- and proto-industrial England. These people based their actions on "a belief that they were defending traditional rights and customs" (Thompson 1971: 78) rather than following their own interests. Thompson's aim was to frame the uprisings, associated by other historians with "degeneration" (1971: 76) and "plunder", in a less "instinctive" (1971: 77) and savage way. ${ }^{2}$ In his view, the protests were more than a "rebellion of the belly" (1971: 77) since they expressed historic ideas about the common good, fairness and appropriateness, as well as a critique of those who profited from the (new) market logic of capitalism. Although the rebellions were triggered by rising prices, abuses of office, and starvation, people protested not only because of their 
individual plight but also against a liberal market economy and a political system which allowed and encouraged the profits of a few at the expense of the many. Instead of reacting in a "spasmodic" (1971: 78) and irrational way, protesters acted "upon a consistent traditional view of social norms and obligations, of the proper economic functions of several parties within the community, which taken together, can be said to constitute the moral economy of the poor." (1971: 79) This view, which casts the protests as a political act rather than as an atavistic impulse, was "passionately held"(1971: 79).

Thompson has been criticised for imposing his Marxist views onto historic agents and thus romanticising pre-industrial economies. ${ }^{3}$ While this makes for a fair argument especially regarding his earlier work, the use of the term moral economy does not automatically imply social romanticism. Moral economy does not describe a warmer and better form of economic exchange and it is not used in order to introduce a moral perspective as an authoritative tool in analyses. Nor should the concept be used to position oneself as a researcher (Suter 2016: 118). Its merits, rather, lie in the complex ways in which it allows one to explore conflicts of moral and legal positions and reasoning. The study of a moral economy examines situations and phenomena in which idioms, narratives, and practices of historical agents collide. These cognitive dissonances and their social negotiations become focal points for explaining why people sometimes act against their own interests. This take on moral economy is the basis of James Scott's analysis of the rural economies in today's Myanmar and Vietnam (Scott 1976). Scott is particularly interested in the peasants' ethic of subsistence. Rather than rebellions, he studied resistance and the conditions that led to uprisings in the 1930s. The economic strategies of the peasants were not directed towards maximising profit, but rather at minimising the risk of food scarcity and hunger. This security of subsistence binds the peasant to the landowners and to their community. The moral economy of the peasant is thus based on a class-oriented paternalistic system managing the expectations and preferences of landowners and peasants and is defined by social values rather than by food prices and market logics. However, and very much in line with Thompson, the moral economy is based on traditional ways of sharing and on a system of solidarity which is interrupted by liberal market economies. Both authors share this political message and the significance of a class consciousness within the moral economy of the poor or of the peasant.

More recently, historian Laurence Fontaine used the concept to analyse pre-industrial modes of giving and receiving credit (and trust) in Europe. Just as Thompson and Scott did earlier, she placed economic activities firmly within a web of class relations (Fontaine 2008). Credit was used to turn economic obligations into social bonds and created, regulated, and eroded social ties. Fontaine emphasised that this paternalistic form of embedded economy constitutes 
stability on the one hand while establishing dependency and subordination on the other. For the eighteenth century, however, Fontaine detected a shift in the credit discourse: The growing middle classes emancipated themselves from their social obligations by framing credit more as an economic transaction than a moral obligation. Disembedding the credit economy, for example by introducing financial institutions, standard rates, time limits, and a competitive market of credit brokerage, freed debtors from their moral obligation and eventually made way for equality and democracy in rural France (Fontaine 2014: 297-320). Fontaine used moral economy as a concept linking debt discourse and practices to social class and a class-specific debt discourse.

While such studies of moral economies focused on areas of historic economies, Lorraine Daston expanded the concept by applying it to the history of the social sciences and the changing argumentation when producing, constructing, and legitimising knowledge (Daston 1995). She thus not only widened the concept beyond economy as the production and circulation of wealth in pre-modern society (as did Thompson, Scott, and Fontaine), she also expanded the notion by stressing the intimate connection of values and emotions. Her definition of moral economy is "a web of affect-saturated values that stand and function in well-defined relationship to one another". Their logic is dynamic and contingent, but not arbitrary: "Although it is a contingent, malleable thing of no necessity, a moral economy has a certain logic to its composition and operations. Not all conceivable combinations of affects and values are in fact possible." Altogether, it is "a balanced system of emotional forces with equilibrium points and constraints" (Daston 1995: 4). Moral economy is about the appropriate, desirable and existing connectivity of society (Tellmann 2013), about the aptness of practices and images in the process of constructing an (economic) subject between individual preferences and collective opinions and expectations.

To emphasise this contingency, Daston used the term in the plural rather than in the singular. Her main contribution, in any case, was her emphasis on emotions and affects in the system of moral economies. Emotions are stabilising and challenging factors, because social structures, norms, and obligations need to be felt in order to be effective. Morality is thus part of constituting a social subject brokering individual priorities with common expectations and obligations. Monique Scheer (2012) pointed out that emotional practices can be read as a form of social self-positioning. By naming and communicating emotions, individuals take on a specific subject position.

Despite her merits for reintroducing moral economy into the academic discourse, Daston has also received criticism for depoliticising the concept. In her work, the model of moral economy is no longer used to describe an unjust social order. It is this political dimension that Didier Fassin wished to re-introduce in his 
work on the moral economy of immigrant labour. He defined moral economy as "the production, distribution, circulation, and use of moral sentiments, emotions and values, and norms and obligations in social space." (Fassin 2009: \$37). In his analysis of the social status of refugees, he compared the narratives of flight (risk management, finances, and expressions of emotions) and reasons for leaving home (political suppression, lack of religious freedom, or sexual orientation) and argued that within the general discursive frame of gender sensibility and sexual democracy, the moral hierarchy has shifted. People have more chance of receiving asylum when they cite genital mutilation, forced marriage, politically motivated rape, forced prostitution, and homosexuality as reasons rather than political suppression or economic suffering (Fassin 2016).

While Fassin succeeds in recouping the political dimension in the notion of moral economy, the question remains whether the term moral economy is the most appropriate for his analysis. In fact, we could also ask whether in Fassin's and Daston's work the terms 'discourse' or even 'culture' are similarly suitable. Compared to those terms, the notion of moral economies has the added value that it accounts for class-informed traditions and frameworks of sense-making (Palomera \& Vetta 2016). Without this perspective, "if simply equated with 'values' and emptied of class content, moral economy loses its raison dêtre" (Palomera \& Vetta 2016: 414). In discussions of what is fair, just, and appropriate, the aptitude of a narrative depends on a social position of the subject and only makes sense in this framework. What connects an individual interest with the "mental states of collectives" - what Daston further described with Ludwig Fleck's terminology of "Gefühls- as well as a Denkkollektiv" (Daston 1995: 4-5) -is the notion of a class-informed identity. By returning to the concept's roots in the works of Edward Palmer Thompson and taking class into the equation, we can answer the question of who decides what is appropriate, wise, and resourceful for whom by taking class into account.

\section{The Debt Crisis in Germany and the Moral Economy of Thrift}

Private debts and insolvency are social problems that have gained prominence in Germany since the 1990s. The changing economy and its effects on employment, the modification of the welfare system, alterations in consumer options and consumer behaviour (for example, credit cards, online shopping, and leasing offers), and, most of all, a new and more liberal credit policy by banks and department stores as well as the introduction of a subprime credit market in Germany led to financial crises not only in working-class, but also in middle-class households. In 1999, private debts made up 74 percent of the gross domestic product in Germany, higher than in the US (70 percent) and in the UK (72 
percent) (Mertens 2015: 16). Social and political pressure ran so high that the government introduced a new insolvency law. Since 1999, it is possible to declare private bankruptcy, which means that a "righteous debtor" (InsO \$1, meaning a bona-fide citizen) can be discharged of residual debts after a period of good conduct. The entire proceedings usually last about four to six years (with four years being the current length of the period of good conduct). They comprise a series of restrictions and obligations like the duty to work or apply for work, to allow access to one's financial affairs and to inform the credit counsellors about change of address and other matters (Meyer 2017: 328-360).

On top of these obligations, during the period of good conduct, it is necessary to practise, express, and even feel thrift in economic behaviour. Through specific thrift capabilities such as prudent housekeeping, bargain shopping, repairing, re-using, DIY, and gardening, the individual manages to participate in the world of consumption without spending too much money. At the same time, it complies with imperatives of sustainability, subsistence, and ethical consumption. The thrifty subject thus achieves a positive way of self-positioning; thrift produces "a social payoff" (Podkalicka \& Potts 2014: 233). This payoff can be derived from expressions of frugality as well as from statements of class-based taste, of citizenship, of ethical consumption, or of political protest. The moral order of thrift implies "society's 'yeses' and 'nos' - that are not only embedded in its laws and governing institutions but are more or less internalized, so that they become 'second nature' to most of the people who constitute society.' (Yates \& Hunter 2011: 12)

Demonstrating thrift can therefore mend financial failures like debts. When debtors demonstrate an awareness of thrift, they show a recognition of a social norm and acknowledge its values of modesty, unpretentiousness, and simplicity. In the debt discourse, they thus take on a subject position of the "righteous debtor" leading a life of "good conduct". This process to become a "righteous debtor" through thrift is basically the plot of the popular reality TV show Raus aus den Schulden (Getting Out of Debt). From 2007 to 2015, the show ran on the private channel RTL with a market share of between 15 and 23 percent, with up to 5 million viewers per broadcast. It was centred on the counsellor Peter Zwegat, who used to work for a public debt administration in Berlin and was cast as the show's protagonist. The show was broadcast at prime time and quickly became a huge success, with twelve seasons and several special episodes. Each episode presents a case where debt counsellor Peter Zwegat is summoned to help out debtors by appealing to their conscience, sorting out paperwork, talking to creditors and employers, and generally guiding them through insolvency. The protagonists are real people with real financial problems who have applied and been cast for the show. Bank clerks, employees of job centres, revenue offices, and creditors are also real. 
Each episode opens with a summary of the-often hopeless-situation of the indebted individuals. It includes the introduction of the indebted protagonists, their household and family affairs, and how they got themselves into debt. The audience receives intimate information about parenting and schooling problems, relationship crises, unfaithful partners, divorce and separation, financial mismanagement, and expensive lifestyles. Through emotional portrayals, intimate details, and authentic locations, the show feeds the voyeuristic desire of its audience. Next, counsellor Peter Zwegat is introduced. In the trailer, action music is used to underline his heroic appearance, the counsellor is shown striding purposefully down a street or in action at his desk, at the telephone, briefcase in hand. When he arrives at the scene, he introduces himself with the slogan: "You called, here I am." Dramaturgically, his appearance marks a turning point in the life of the debtor. The camera then takes us into the home of the protagonists, showing place names and doorbell plates to create authenticity. Viewers are shown the (often slightly too big) size of the house or flat, the number of children and pets, the (extravagant) interior design, the (numerous) possessions like clothes and shoes, the (exquisite) foods, the (expensive) hobbies and means of transport, and the (latest) gadgets and media equipment. From all these (not so subtle) clues we derive our judgment about failure or success in the financial crisis. Take, for example, the case of Marco S. (21 years old) and his girlfriend Marina (20 years old) from Lüdenscheid. After finishing school, Marco took up a trainee position at McDonalds and also began his career as a consumer (S8, E8 "Marco S. und Marina D. aus Lüdenscheid", first broadcast 27/10/2010). ${ }^{4}$ When he explains to the camera how he buys gadgets without having to pay for them, his words are underlined with images of a room cluttered with equipment like a brand new film camera, an entertainment system with TV, PlayStation, and DVD player, and an amplifier (0:10-0:15). We also learn that the couple owns two laptops on lease, an iPhone, and have subscribed to the pay-TV station Sky (4:08-4:37). After this demonstration of overconsumption on credit, the camera zooms in on a pile of documents. Marco admits that he does not know how much he owes because he has thrown away most of the bills and reminders. This manner of-or rather lack of-filing serves as a demonstration of indifference and apathy. In every episode, Zwegat asks his clients to bring their debt papers and, from the way they return with files either neatly filled with documents or with baskets full of loose letters, requests, and reminders, the audience is given a clear image of the respective debtor and his or her financial destiny.

After Marco confesses that he does not know the amount he owes, the camera pans into the bathroom where dishes pile up in the shower (5:26), the cut suggesting a strong link between financial and domestic chaos. More dishes are stacked in another room, while the voice-over informs the viewer that Marina's parents gave 
the couple a kitchen interior which is, however, still being stored in the nursery. The camera roams through the rooms showing unpacked boxes and unassembled pieces of furniture, none of which is in place or functional (5.26-5:55). The message again is one of thrift incompetence and a lack of housekeeping skills. Although they are given furniture for free, they do not manage to create a home with it. Being either messy or tidy becomes a moral issue in the TV show, associating dwellings with guilt and lack of control (Löfgren 2014: 88-90).

During the episode, no stereotype of the deadbeat is left out. We learn that the couple rarely get up before $11 \mathrm{am}$, they are unable to fill in a form in order to apply for welfare, and they do not even know where to find a mailbox (while the camera shows one standing in front of the house). While Peter Zwegat looks around the flat, the voice-over delivers facts and figures about the three rooms (two bedrooms) - "56 square metres, 256 Euros rent"-just as soberly and gloomily as the images portray the dwellings. The unfinished nursery in particular is shown as a careless environment full of junk. The semiotics of stuff are conveyed not only by the objects themselves but also by their arrangement, or rather non-arrangement, in "non-descript heaps, bundles, piles, assemblage" (Löfgren 2014: 84). The throwntogetherness of stuff is shown as the opposite of a working order in housing, documentation, and finances. The couple's lack of concern for their finances is paralleled with their lack of taste and their inability to create a homely and comfortable environment. When Marco und Marina again fail to collect relevant documents and fill in forms, Peter Zwegat takes them to a nearby bridge as the final symbol of living homeless and depicts their prospective life under the bridge in strong language (24.14-26:08).

Appropriate emotions are an important part of any moral economy. In the TV show, feelings are linked to numbers, i.e. debtors are expected to show shame, astonishment, frailty, desperation, or defiance when Peter Zwegat begins to do the maths. The debtors are shown seated in their homes, the camera filming close to their faces. The counsellor stands opposite at a flip chart, calculating income and expenses in excruciating detail with a red pen. Visually, these lists are superimposed over the picture of the debtor, thus debts are linked to a name and a face. The close-ups enable the viewer to study their emotions in detail: narratives and idioms of shame, guilt, and regret are juxtaposed with scenes of indifference, disdain, and aggression. In both cases, the recognition or violation of a normative social order is represented. This emotional practice is a cornerstone in the process of debt relief. In many cases, debtors express their feelings of guilt along with a sense of responsibility and initiative. In Marco's case, rather than showing the discursively appropriate emotions of shame, remorse, and guilt, he is pictured showing indifference, defiance, and anger, which adds to the image of him as an unreasonable and undiscerning person. Just like his actions, his emotions are 
not appropriate. He plays the role of the moral hazardeur who sponges off his mother and milks the state for support while borrowing more and more money. By maximising his benefits and minimising his effort, he might show financial shrewdness but offends the moral economy of thrift. It does not come as a surprise that the reason for his debts is as superficial as his endeavour to get out of debts. He quit his job and went shopping because, in his words, "I just wanted to be free and do whatever I felt like doing, no boundaries, enjoy my life to the full" (05:00-05:10). The scene is repeated in the trailer and can be seen as a condensed version of the moral economy of (non-)thrift. Not only is he economically incompetent and disorganised, Marco is also portrayed as selfish, superficial, and irresponsible. His irritation with the world of debts is materialised in gadgets, junk, and mess. On the screen, he repudiates the moral economy of thrift by acquiring stuff without using it. His clueless rebellion against the financial order is echoed in this production of disorder, a subversive comment on taxonomies of order and mess, value and trash (Dion, Ouidade \& Guillard 2014).

A very different case can be seen with the single mother Nicole $\mathrm{K}$. from Bielefeld (S9, E11 "Der Fall K. aus Bielefeld", first broadcast 9/11/2011). ${ }^{5}$ At the beginning of her story, we follow the camera towards a bland white apartment building in a housing estate. Inside, we meet the 32-year-old debtor and her son Darren-Lee (11 years old) and learn that, after her wild youth without finishing school, running away several times and doing drugs, she has been in debt for more than a decade. Now, at the age of 32, she wants to turn her life around: She goes back to finish school; she wants to be a role model for her son and to show him that "it is never too late" to achieve one's goals with "a little bit of diligence and motivation" (1:25-1:38). Demonstrating thrift skills, she "has studied a lot and worked hard" and now wants to keep going (2:20-2:25). The tour through Nicole's home shows a spotless and comfortable flat. According to the voice-over, the furniture is second-hand and simple but tastefully arranged, the rooms are tidy, even Darren's small room is very neat with a made-up bed and folded clothes (9:52-10:48). In a simple but orderly kitchen, we can see her preparing a healthy tomato salad for her son. Thrift competence, i.e. making the most of a small budget, is shown as cultural capital.

The interviews with Nicole are filmed in the living room. Behind her, there is a filing system with labelled trays in place, and we can also see an old $\mathrm{TV}$ and a computer. All the scenes convey an impression of order, tidiness, and understatement, underlining the sincerity with which Nicole wants to master her life and her debts. When asked for her documents, she brings in a shoebox with neatly stacked files (14.55-15:12). These sympathetic visual assessments of her character are accompanied with an emotional scene in which she confesses how scared she is about her son's future. Here, tears well up in the otherwise very 
composed woman's eyes. Her devotion to her son combined with the images of determination, diligence, self-initiative, and tidiness frame her as a good debtor. Although she ran into debt for much the same reasons as Marco, i.e. "out of stupidity, bad luck, and naivety", the cultural capital of thrift helps her out of debt in a socially acceptable manner.

In the TV show, the social script of being in, and being relieved from, debts uses the moral economy of thrift as a reference point. However, thrift competence refers not only to patterns of consumption and financial decisions. Thrift here implies a consciousness about middle-class values, cultural capital and social positioning. The well-balanced system of the appropriate use of resources includes emotions (showing care and affection towards family members as a motivation for spending, taking responsibility, and regretting bad decisions), values like education, industriousness, and diligence, practices of order (filing, providing healthy food, keeping simple, clean dwellings, and demonstrating work ethics and diligence). This constitutes the appropriate state of mind when aspiring for a financial and moral discharge. The close-up and detailed portrayal of dwellings provides evidence of an attitude of thrift: Orderly homes and tidy filing represent notions of accuracy and correctness, including in one's finances; modest interiors, cars, and hobbies show a sense of suitable and appropriate consumer habits. The financial crisis is thereby linked to an appropriate middle-class lifestyle (not too fancy but not too gloomy either, frugal but tasteful and, most of all, tidy and proper). Thrift is the touchstone of endowing finances and consumption with attributions of good and bad, of appropriateness and extravaganza, in short: with appropriate ways of living.

\section{Micropolitics of Debts TV in Germany and in the US}

Whereas the simplistic portrayal of the good and tidy as opposed to the bad and messy debtor is rather stereotypical and follows-as well as reinforces-the predominantly negative image of debtors, the figure of the counsellor is more complex, offering insights into debt regimes and their potency with debtors. When Peter Zwegat is introduced, he is shown in front of the Reichstag, the seat of the German government, the location (and dwelling) underlining the public mission and mandate of the counsellor. However, in terms of governmental studies, his appearance is not that of a state authority or a teacher; he does not reinforce regulations or lecture about the rights and wrongs of debts discharge. Rather, he represents "the voice of reason" and "the people's voice" (mark the iconography of the Reichstag and the German flag). His authority is mandated by public opinion and thereby achieves normative efficiency (Nohr 2014). He provides advice rather than rules, his character is all about self-guidance rather than instructions, an 
incarnation of the governmentality of debts. The micropolitics of TV thus work as a process of subjectivisation at the intersection of internal and external guidance (Seier 1991).

The specifics of Zwegat's character become even clearer when compared to his US colleague Victor Antonio from the TV show "Life or Debt". Introduced as a business strategist, Antonio takes the role of a straightforward and tough, sometimes rude individual, telling his clients what (not) to do and, time and again, how stupid they are. Overall, however, he is shown as a likeable man who is driven by the same aim as Zwegat, which is to help clients out of debt. But, as can be seen in the trailer for season one, Victor Antonio wants to "teach" his clients, he is going to "kick their arse", they have "to pay the price (...) crawl through the glass". ${ }^{6}$ There is a lot of swearing and shouting, arguments about consumers' choices, like a room full of shoes which Antonio reacts to with "are you $\mathrm{f}^{* *}$ ing kidding me?", expensive cars ("how does an executive assistant drive a hundred-thousand-dollar car?"), and entertainment units. We are shown cluttered rooms, messy garages, and piles of documents ("this is not an office, this is a junk hole!"). Again, homes are used to portray people as irrational, short-sighted, and selfish, in one word: unthrifty. But whereas Peter Zwegat raises his eyebrows and looks reproachfully at the debtors, Victor Antonio blames his clients vociferously and swears at them.

Another striking difference between the two shows is the way we learn about the debtors' homes. The US show has a camera installed in the house which Victor Antonio uses to assess the behaviour of his clients, when they get up in the morning, whether they keep their home tidy, and clean up after meals. The debtors are monitored in their home whereas Zwegat relies on self-control. Life or Debt is about an external regime setting people straight financially whereas Raus aus den Schulden is about accepting moral responsibility as the way out of debt. Victor Antonio is angry with his clients when they do not obey him, while Peter Zwegat is disappointed in them when they do not take his advice. The show offers a way out of debt not by following financial rules but by implanting self-technologies and thus optimising the indebted self (Meyer 2017). Both shows work with popular strategies from reality TV like personalisation and authentication, showing private situations and intimate scenes and, most importantly of all, using emotions (Bente \& Fromm 1997, Ouellette \& Hay 2008, Palmer 2003). In both shows, there is a lot of crying, despair, anger and, eventually, rays of hope. The difference lies in the morality of the message with regard to social positions. In the US, debts and bankruptcy have long been a normality in middle-class circles (e.g. Sullivan, Warren \& Lawrence 2000). Thrift is seen more as an economic tool than a moral order. In Life or Debt, debts are portrayed as the result of a wrong business decision, a poor investment, a high risk, or living beyond one's means. A financial crisis can happen to anybody, regardless of social background. And, following the 
American dream, anybody can get out of debt, as long as they clean up their act and try hard enough. In the German show, Zwegat's pedagogical programme uses thrift as a class-based ideal one needs to aspire to because it promises a way out of debt as well as a feeling of social inclusion and exclusion. Thrift here carries the moral weight of being or not being middle-class, of doing the right thing not only financially, but also morally.

A similar conclusion can be drawn from comparing the two national laws on personal bankruptcy: The German law promotes "the righteous debtor" as defined by their "good conduct"; debtors need to prove themselves worthy of having their residual debt discharged. The US legislative by contrast offers debtors a "fresh start" as soon as they declare themselves bankrupt (Napoletano 2012) and, rather than stigmatising debtors, the law offers them economic agency by promptly reintroducing debtors into the consumer market.

\section{Conclusion: Risk Management or Struggling with Class? De-politising Debt}

Overcoming debt financially and morally is dealt with differently in the US and in Germany. The US insolvency law is not a pedagogical programme based on years of good conduct and righteousness, on the contrary: It leads to an immediate discharge in order to allow a fresh start for the consumer. As can be derived from TV visualisations, debt relief in the US context is based on entrepreneurial reasoning-Antonio repeats the phrase that households have to be run and guided out of debt like businesses-whereas the German show underlines the role of hardship, guilt and good conduct in the debt relief programme. Thereby, the regime of debt relief reproduces an inner industry of the indebted self and suppresses transitions of economic structures like the employment market and changes in the welfare state. The inner industry is visualised on TV in thrift practices, proper dwellings and living conditions.

With the role of thrift, the struggle with debt in Germany becomes a class issue. While middle-class oriented debtors possess enough thrift competence to achieve good conduct and thus a moral discharge, other debtors fail to do so. The German insolvency discourse is another example of what Loïc Wacquant calls the Centaur-state which encourages social inequality by an ambivalent class system:

[A] Centaur-state [...] displays opposite visages at the two ends of the class structure: it is uplifting and 'liberating' at the top, where it acts to leverage the resources and expand the life options of the holders of economic and cultural capital; but it is castigatory and restrictive at the bottom, when it comes to managing the populations destabilised by 
the deepening of inequality and the diffusion of work insecurity and ethnic anxiety. Actually existing neoliberalism extolls 'laissez faire et laissez passer' for the dominant, but it turns out to be paternalist and intrusive for the subaltern, and especially for the urban precariat whose life parameters it restricts through the combined mesh of supervisory workfare and judicial oversight. (Wacquant 2012: 74)

However, the structural element of class in the neoliberal debt economy is hardly addressed in the TV show. Problems like a subprime credit market for those who do not have access to the prime section, socially unequal terms of financialisation, and the ramification of a changing law on people without education or long-term unemployment are not made the subject of discussion. ${ }^{7}$ Accordingly, it is up to the individual to solve their problem, whereas banks, the finance market and the state legislative is off the hook. Debts are thus depoliticised, they are no social problem but personal ones. And while some can deal with those problems because of their social background and access to capital like thrift, others cannot and have to take the blame.

Silke Meyer is professor at the Department of History and European Ethnology at the University of Innsbruck. Her research interests encompass economic anthropology, debts and credit, transnationalism, migration and remittances. Recent publications include a monograph on the indebted self and narratives of private insolvency (published with campus 2017).

\section{Endnotes}

${ }^{1}$ The term moral economy has provoked renewed interest especially since the financial crisis of 2007/08. Recent, more general papers by Carrier (2018), Götz (2015), and Siméant (2015) give useful overviews of the history of the concept. Palomera and Vetta (2016) as well as Fassin (2009) re-politicised the concept by bringing back social class and capital.

${ }^{2}$ Thompson also criticised the use of "the unsatisfactory term of riots" (1991: 260), given that after the Riot Act of 1714, any outdoor congregation was declared illegal. Calling the protestor rioters, even in retrospect, thus suggests that they were criminals. I would like to thank Niels Grüne for this information.

${ }^{3}$ For example, James Scott: The Moral Economy as an Argument and as a Fight. In: Adrian Randall \& Andrew Charlesworth (eds.): Moral Economy and Popular Protest: Crowds, Conflict and Authority. Basingstoke 2000, S. 187-208. In his later review, Thompson himself conceded that the problem centred on the word "moral": "Moral' is a signal which brings on a rush to the academic head. Nothing has made my critics angrier than the notion that a food rioter might have been more 'moral' than a disciple 


\section{Culture Unbound}

Journal of Current Cultural Research

of Adam Smith." (1991: 271)

${ }^{4}$ The episode is available here: https://www.dailymotion.com/video/x6rso7z (accessed 29/1/2019)

5 The episode is available here: https://www.dailymotion.com/video/x5z6e41 (accessed 29/1/2019).

6 The trailer is available here: https://www.youtube.com/watch?v=beR6vBTS27o (accessed 29/1/2019).

7 This phenomenon is, of course, not new, see David Caplovitz' classical study on the reasons why the poor pay more.

\section{References}

Caplovitz, David (1967): The poor pay more: consumer practices of low-income families. New York: Free Press.

Carrier, James G. (2018): "Moral economy: What's in a name," Anthropological Theory, $18: 1,18-35$.

Daston, Lorraine (1995): “The Moral Economy of Science," Osiris, 2nd ser., 10: 2, 2-24.

Dion, Delphine, Sabri Ouidade \& Valérie Guillard (2014): "Home Sweet Messy Home: Managing Symbolic Pollution," Journal of Consumer Research, 41, 565589.

Fassin, Didier (2009): "Moral economies revisited," Annales. Histoire, Sciences Sociales, 64:6, 1237-1266, English version here: https://www.cairn-int.info/article-E ANNA 646 1237--moral-economies-revisited.htm\#re1no1 (accessed 28/1/2019).

Fassin, Didier (2016): "Vom Rechtsanspruch zum Gunsterweis. Zur moralischen Ökonomie der Asylvergabepraxis im heutigen Europa," Mittelweg 36: Wandern. Zur Globalgeschichte der Migration, 25:1, 62-78.

Fontaine, Laurence (2014): The moral economy of credit. Poverty, Credit, and Trust in Early Modern Europe. Cambridge: Cambridge UP.

Götz, Norbert (2015): "Moral Economy: Its Conceptual History and Analytical Prospect," Journal of Global Ethics, 11:2, 147-162.

Life or Debt, trailer, Spike TV.

Löfgren, Orvar (2014): "The black box of everyday life: entanglements of stuff, affects and activities," Cultural Analysis, 13, 77-98.

McCloskey, Deirdre (2011): "The Prehistory of American Thrift," James D. Hunter \& Joshua J. Yates (eds): Thrift and Thriving in America. Capitalism and Moral Order from the Puritans to the Present. Oxford: Oxford UP, 61-87.

Mertens, Daniel (2015): Erst sparen, dann kaufen? Privatverschuldung in Deutschland. Frankfurt am Main/New York: campus.

Meyer, Silke (2017): Das verschuldete Selbst. Narrativer Umgang mit Privatinsolvenz. Frankfurt am Main/New York: campus.

Napoletano, Gino (2012): Privatinsolvenz und Restschuldbefreiung: Fresh Start oder "bürgerlicher Tod"? Rechtspolitische Überlegungen zur Entschuldung natürlicher Personen unter besonderer Berücksichtigung ökonomischer Aspekte. Hamburg: Dr. Kovaç.

Nohr, Rolf F. (2014): “SuSi-Fernsehen. Beratung, Empowerment und Denormalisierungsangst," Andrea Seier \& Thomas Waitz (eds): Klassenproduktion. Fernsehen als Agentur des Sozialen. Münster: LIT, 193-212.

Ouellette, Laurie \& James Hay (2008): Better Living Through Reality TV: Television and Post-Welfare Citizenship. Malden, MA: Blackwell.

Palmer, Gareth (2003): Discipline and Liberty. Television and Governance. Manches- 
ter: Manchester UP.

Palomera, Jaime \& Theodora Vetta: "Moral economy: Rethinking a radical concept," Anthropological Theory, 16:4, 413-432.

Podkalicka, Aneta \& Jason Potts (2014): "Towards a general theory of thrift," International Journal of Cultural Studies, 17:3, 227-241.

Raus aus den Schulden, "Marco S. und Marina D. aus Lüdenscheid", probono Fernsehproduktion GmbH, RTL, October 272010.

Raus aus den Schulden, "Der Fall K. aus Bielefeld", probono Fernsehproduktion $\mathrm{GmbH}, \mathrm{RTL}$, November 92011.

Scott, James C. (1976): The Moral Economy of the Peasant. Rebellion and Subsistence in South East Asia. New Haven: Yale UP.

Seier, Andrea (2009): "Mikropolitik des Fernsehens. Reality-Fernsehen als Regierung aus der Distanz," KultuRRevolution. Zeitschrift für angewandte Diskurstheorie, $45,47-52$

Siméant, Johanna (2015): "Three bodies of moral economy: the diffusion of a concept," Journal of Global Ethics, 11:2, 163-175.

Suter, Mischa (2016): Rechtstrieb. Schulden und Vollstreckung im liberalen Kapitalismus 1800-1900. Konstanz: Wallstein/Konstanz UP.

Tellmann, Ute (2013): "Verschulden. Die moralische Ökonomie der Schulden," ilinx. Berliner Beiträge zur Kulturwissenschaft, 3, 3-24.

Thompson, Edward Palmer (1971): "The Moral Economy of the English Crowd in the Eighteenth Century," Past \& Present, 50:1, 76-136.

Thompson, Edward Palmer (1991): The Moral Reviewed. Customs in Common: Studies in Traditional Popular Culture. New York: Merlin, 259-351.

Wacquant, Loïc (2012): "Three steps to a historical anthropology of actually existing neo-liberalism". Social Anthropology/Anthropologie Sociale 20, 1, 66-79. 